\title{
Ürün Özelliklerinin Bireylerin Tutumları Üzerindeki Etkisi
}

\author{
Mustafa Portakalc1*
}

Yakın Doğu Üniversitesi, İletişim Fakültesi, Halkla İlişkiler ve Tanıtım Bölümü, Lefkoşa

\begin{abstract}
Öz
Bireylerin tutumlar üzerinde ürün özelliklerinin etkisinin belirlenmesi ve hangi özelliklerin ön planda olduğunu belirlemek amacıyla yapılmış olan bu araştırma; Kuzey Kıbrıs Türk Cumhuriyeti'nin Lefkoşa, Girne ve Gazimă̆usa ilçelerinde olasilikl olmayan örnekleme yöntemi ile belirlenen 18 yaş ve üzeri 480 kişi araştırma kapsamina dahil edilerek gerçekleştirilmiştir. Araştırma verilerinin toplanmasında yüzyüze görüşme yoluyla anket tekniğinden faydalanılmıştır. Araştırmada; ilçe, yaş, aylık gelir ve meslek değişkenlerine bağh farklhliklarm belirlenmesi için t-testi'ne (independent samples $t$ test) ihtiyaç duyulmuştur. Katılımcıların eğitim durumları ile ilgili alt boyutların karşılaştırılmasında ise Mann-Whitney $U$ Testi ve Kruskal-Wallis $H$ Testi uygulanmıştır. Çalışmada ayrıca ilçe, yaş, aylık gelir ve meslek değişkenlerine bağgl farklllikların belirlenmesi için Tek Yönlü Anova (one way ANOVA) yapılmış, farklılığın hangi gruplardan kaynakladı̆̆g ise Tukey testi ile belirlenmiştir.
\end{abstract}

Anahtar Kelimeler: Ürün, Ambalaj, Moda, Logo

\section{The Impact of Product Features on Attitudes of Individuals}

\begin{abstract}
This research was conducted to determine the effect of product characteristics and the most important features on the attitudes of individuals. Using a non-random sampling method, 480 respondents aged 18 and over living in the districts of Nicosia, Kyrenia, and Famagusta in the Turkish Republic of Northern Cyprus were selected and face to face questionnaires were conducted. In the study, T-test (independent samples $t$ test) was used in order to determine the differences between variables of district, age, monthly income and occupation. Respondents were asked to compare the size of the training cases is related child with Mann-Whitney $U$ Test and Kruskal-Wallis $H$ Test were applied in order to determine the differences between educational status of respondents. In order to find out the differences between the district, age, monthly income, and occupation, one way Anova (one way ANOVA) was applied and to determine the different group Tukey test was used.
\end{abstract}

Keywords: Product, Packing, Fashion, Logo

\section{Gíriş}

Küreselleşmeyle birlikte dünyada yaşanan siyasal, sosyal, ekonomik ve teknolojik değişimler beraberinde gelişim gösteren teknolojik gelişmeler, üretim biçimlerindeki değişim, büyük çapta üretim yapabilme olanakları, artan tüketici sayısı, değişen tüketici beklenti ve istekleri gibi sebepler işletmelerin pazarlama faaliyetlerinde pazarlama iletişimi olgusunu önemli duruma getirmiştir. Küreselleşmenin etkisiyle kalabalıklaşan pazarla birlikte artan rekabet ortamında pazar payı elde etmek isteyen işletmeler kazandıkları payı sonrasında korumak ve büyütmek amacını taşımaktadır. Bunu gerçekleştirebilmenin yolu ise, bireylerin istek ve ihtiyaçlarına uygun ürünler sunmaktan ve hedef kitlenin güvenini kazanmaktan geçmektedir. Bu bağlamda işletmeler hedef kitlelerine ulaşmada birçok yöntemden 
faydalanmaktadırlar. İşletmeler hedeflerine ulaşmada kullandıkları yöntemlerden biri de içinde yer aldığı pazar ortamında ürünlere ayırt edici özellikler sunarak rakipler arasında fark yaratacak özellikler ortaya koymaktır. Üretilen ürün ve hizmetleri hedef kitleye sunan işletmeler, ürünler hakkında bilgiyi bireylere sunarken aynı zamanda ürün özelliklerini ön planda tutarak hedef kitlelerin tutumlarını ve alışkanlıkları da etkileyebilmektedir. İşletmeler bu etkinin gerçekleşebilmesi noktasında reklamlardan faydalanarak ürünlere özellik kazandırıp, bireyleri piyasaya sunulan ürünleri satın almaya yönlendirmektedir. Bu noktada işletmeler reklamlar aracılığıyla ürünlerini hedef kitlelere tanıtırken ürünlerin moda olmasını sağlarken aynı zamanda ürünlerin logo, amblem gibi özellikleri ile fark yaratmakta, oluşturulan bu özellikler ile tüketicilerin satın alma davranışını harekete geçirerek tutumlarında belirleyici olabilmektedir. Bu işlevi reklamlar, tanıttıkları mal ve hizmetlere çeşitli anlamlar yükleyerek yerine getirmektedir. Oluşturulan ürünlerin özellikleri hedef kitlelerin tutumlarının belirlenmesi bakımından belirleyici olabilmektedir. $\mathrm{Bu}$ anlamda işletmeler tüketici anketlerine başvurmaktadır. İşletmeler bu ihtiyaçlarını çoğu zaman özel araştırma şirketleri tarafından yapılan araştırmalarla gidermeye çalışmaktadır. Akademik anlamda ise işletmelere örnek olabilecek bazı çalışmalar da bulunmaktadır. Bu çalışmada, bireylerin tutumlarında ürün özelliklerinin etkisi tespit edilerek hangi özelliklerin ön planda olduğu belirlenmesi açısından önem arz etmektedir.

\section{1. Ürün}

Ürün, bir veya daha çok ihtiyacı karşılayabilen soyut-somut faktörlerin bir bileşkesi olarak tanımlanmaktadır (Çalışkan, 2008: 10). Ürün, üretici firmalar ile hedef kitleler arasında bağlantı kurma görevini üstlenmektedir. Çünkü bireyler işletmeyi çıtı olarak sunum yapan üretim birimleri şeklinde algılamaktadır. Dolayısıyla, ürün imajının nasıl olması gerektiği ve ürün özelliklerinin belirlenmesi oldukça önemlidir (İslamoğlu, 2008: 264). Ürün özelliklerinden içerik, şekil, ambalaj, dayanıklılık, tat, koku, imaj, marka ve garanti gibi ürüne yönelik her unsurun bireyin tutumu açısından önemli role sahiptir. Zira ürünler arasındaki farklılıklar tüketiciler bakımından seçenekleri oluşturmaktadır. Tüketiciler de ürünlerdeki bu ayırt edici özellikler çerçevesinde ürünlere ulaşma arzusuna girmekte bunun sonucunda da istek ve ihtiyaçlarını karşılamaktadır. Bu bağlamda ürünü bütün olarak değerlendirip, hedef kitlelere her yönüyle tercih edilebilir şekilde sunabilmek ve pazarlayabilmek işletmelerin devamlılığı açısından önem arz etmektedir (Çevikbaş, 2007: 13). Ürünün hedef kitle olan bireylere ulaşması bakımından önemli bir etken ise pazarlamadır. Pazarlama; ürün ve hizmetlerin, planlı bir şekilde üreticiden tüketiciye aktarıldığı süreç olarak kabul edilmektedir (Baybars, 1999: 38). Tutundurmanın alt bileşeni olarak kabul edilen reklam ise, bu noktada hedef kitle ile üretici arasında bir ilişkisel bağ oluşturarak, tüketiciyi belirli bir ürün ya da hizmeti satın almaya yöneltmeye çalışan bir pazarlama faaliyeti olarak ortaya çıkarmaktadır (Taşyürek, 2010: 24). Bu sebeple pazarlama, bireylerin ihtiyaçlarını merkeze alarak, pazarlama karması içerisindeki tüm aktivitelerin koordinasyonunu sağlamalıdır. Çünkü pazarlamanın temel görevi satış olarak kabul edilmektedir. Ancak kavram ve içerik olarak satış ve pazarlama günümüzde birbirlerinden ayrılmıştır. Günümüzde işletmelerin pazarlama faaliyetleri 
ürünlerin oluşumu öncesinde başlamaktadır. Öte yandan satış ise; bir ürün üretildikten sonra gerçekleşen çalışmalardır. Fakat unutulmamalıdır ki pazarlama, ürünün yaşam süresince devam eden, yeni müşterileri bulmaya çalışan, ürünün çekiciliğini ve başarısını arttırmayı hedefleyen, ürünün satış rakamlarından dersler çıkaran ve tekrarlanan satışları yöneten aşamaları içermektedir (Baban, 2010: 25). Bu noktada günümüzde serbest piyasa ekonomisi içerisinde tüketicilerin amacı piyasadaki yüzlerce ürün arasından en akılcı seçimi yaparak olabildiğince en yüksek faydayı sağlamakken, firmaların amacı da rakipleri arasından sıyrılarak devamlılığını sağlayabilmek için daha fazla satış yaparak kar artışı oluşturmaktır.

\section{1. Ürünlerin sınıflandırılması}

Ürünlere yönelik sınıflandırmalar, pazarlama stratejileri ile tüketicilerin satın alma karar süreci belirlenerek gerçekleşmektedir. En temel sınıflandırma ise ürünlerin farklılaşması için oluşturulan sınıflandırmaların geliştirilmesi veya bir karşılaştırmanın ortaya konulması üzerine oluşturulmaktadır. Bu temel ayrım yapıldıktan sonra, firmalar ürünler üzerine derinlemesine araştırmalar yapmaktadır. Yapılan sınıflandırmalarda en yaygın olarak kullanılanı ise bireylerin satın alma davranışı temeline dayanan, kolayda, beğenmeli, özel ürün ve aranmayan ürün çeşitleridir (Copeland, 1924: 34). Bu kategori türleri pazarlama kavramında hedef kitlenin tercihleri, kararları, marka bağlılıkları, imaj ve beğenileri üzerine yapılan çoğu araştırmada yoğun olarak kullanılan ve firmaların pazarlama stratejilerini saptamaya yardımcı olan sınıflandırmadır (Altunışık ve Baş 2015). Bu farklı sınıflandırmadaki ürün gruplarının, kendine özgü fiyatlandırma, tutundurma ve dağıtım uygulamaları mevcuttur. Bu farklılıkların meydana getirdiği yapılar dikkate alınarak, pazarlama uygulamalarına karar verilmesi bireyin karar sürecinde bilgi arama davranışlarının temelinde yatan ve belirlenemeyen yapısal dinamiklerin açıklanması işletmelerin pazarlama çalışmalarına kolaylık sağlamaktadır (Scott ve Gregg 2004: 277).

\section{Ambalaj}

Ambalajın satın almayı tetikleyen kuvvetli bir satış unsuru olduğu savunulmaktadır (Berkman vd., 1997: 50). Temsil ettiği ürün ve hizmetleri korumaya yarayan ambalaj aynı zamanda kullanıcıya ürünün hakkında geniş bilgi verme özelliğini içermektedir. Ambalaj görsel bir nesne olduğundan etkileyici olması gerekmektedir. Bu sebeple kozmetik sektörlerinde kullanılan ambalaj bazen ürünün kendisinden daha pahalı olabilmektedir. Ambalaj denildiğinde akla gelen ilk unsur; bir ürün dizisindeki maddenin veya ürünün içine konulduğu kap veya konteynerdir. Ürünün çevresini koruyan, taşıma ve depolanmasını, bununla birlikte satışını kolaylaştıran, kısmen veya tamamen atılabilecek veya geri dönüşe uygun bir malzemeyle kaplanması, örtülmesi ya da birleştirilmesi olarak ifade edilmektedir (Tek, 1999: 372). Başka bir tanıma göre ise ambalaj; ürünü dış etkenlerden koruyan, içine konulan malları aynı yerde tutarak dağıtımını kolaylaştıran son kullanıcıya içindeki mal hakkında da bilgi veren metal, kâğıt, karton, cam, teneke, plastik ve tahtadan yapılan kaplamaların genel adıdır (Üçüncü, 2000: 5). Buna göre ambalajlama kavramı; gıdaların üretim sonrası dış etkilerden korunması ve tüketime kadar geçen zaman 
içerisinde gıdaların niteliklerinin değişmesini önleyen zevk ve şekil bakımından tüketicinin ilgisini çekebilme özelliğine sahip maddeler ile yapılan sargı işlemidir (Brody ve Lord, 2000: 2-6).

Ambalajın özelliği, içerisindeki ürün hakkında tüketiciye bilgi vermesi ile alakalıdır. Dolayısıyla ambalaj, ürünün miktarını ve nasıl kullanılacağını belirtmiş olmalıdır. Bununla birlikte ambalajlar ürünleri muhafaza edebilmeli ve kolay açılabilir özelliğine sahip olmalıdır. Ambalajlamada, ürün ambalajının kullanımındaki kolaylık, büyüklük, biçim, hacim, yapılış şekli ve görünüşü, etikete olan uygunluğu vb. hususların da üzerinde dikkatle durulması gerekmektedir. Ambalaj, ürün açısından oldukça büyük bir öneme sahip olduğundan, ürünü her anlamda daha fazla kullanışlı, emniyetli yapabileceği gibi kullanımını da kolaylaştırabilir. Bu nedenle ambalaj, bir marka ismi gibi, tüketicilerin satın alma davranışını etkileyebilir özellikler gösterebilmektedir.

Ürünler arasındaki rekabetin büyük bölümü ambalajlar arasında yaşanmaktadır. İşletmelerin satış yöntemlerinin gelişmesiyle birlikte, satıcıların rolünü önemli ölçüde ambalajlar üstlenmiştir. Ambalaj ile ürün, hem fiziki açıdan hem de kalite açısından korunabilmektedir. Bu anlamda ürünün ambalajlanma işleminden itibaren, ürünün tüketildiği zamana kadar mağruz kalacağ karşı ürünün güvenliğini ambalaj sağlamaktadır (Oğuz, 1997: 22). Aynı zamanda ambalajdaki kolaylık işlevi; malın taşınmasını, depolanmasını ve kullanımını içermektedir. Bu işlevde mal üretilip ambalajlandıktan sonra en son tüketicinin kullanımıyla işlevini yitirmektedir. Piyasada olan ürünlere bakıldığında plastik kapaklı ya da elle yırtılabilen ambalajlar tüketici açısından kolaylıklar sağlamaktadır. Bununla birlikte ambalajsız ürünler hem kalite hem de miktar-fiyat açısından tüketiciye güven vermemektedir. Bu açıdan ambalaj bu güvensizliklerin ortadan kaldırılmasında önemli bir unsurdur. Ayrıca bazı malların nasıl kullanılacağına ilişkin bilgiler de ambalaj üzerinde belirtilerek, kullanımına ilişkin bilgiler aktarılmaktadır (Silayoi ve Speece, 2004: 607).

Pazarlamada önemli bir rol oynayan fiyat-miktar ilişkileri nedeniyle ambalaj boyutlarının da satış üzerinde büyük bir payı vardır. Satın alma gücü yüksek olan pazarlarda ekonomik olan ambalajlı ürünler çok satılmaktadır. Satın alma gücü düşük olan pazarlarda ise tüketiciler ekonomik olan ambalajlı ürünlere para harcamak istememektedirler. Bu nedenle ambalajın boyutları konusunda karar verecek yöneticiler fiyat-miktar ilişkilerini ve tüketicinin satın alma gücünü iyi tespit etmek zorundadırlar (Bozkurt, 2000: 11).

\section{Moda}

Moda sözcüğü ilk kez 14.yüzyılda Elizabeth Wilson tarafından yazılan 'Adorned in Dreams: Fashion and Modernity' adlı kitapta kullanılmıştır. Bu kitapta moda Batı Avrupa olarak belirtilmiştir. Modanın 14.yüzyıldan itibaren büyük şehirlerin ortaya çıkması ile şehirleşmenin başlamasıyla günümüze kadar süregeldiği savunulmaktadır (Wilson, 2003: 16). Moda değişiklik ihtiyacı veya süslenme arzusuyla bireylerin tüketim eğilimlerine yön veren geçici tüketim anlayışı şeklinde belirtilmiştir 
(Batur, 1987: 84). Moda 1960'lı yıllara kadar Simel'in 'yukarıdan aşağıya modeli' ile ifade edilmektedir. Bu model ile 'moda' toplumda taklit edilme eyleminin sergilendiği davranış şekli olduğu savunulmuştur (McCracken 1990: 59-60). Moda kavramı günümüzde her türlü konuda önemli unsur olarak varlığından söz ettirmektedir. Gelinen noktada Moda, bireylerin yaşayışlarına yön veren ve davranış biçimlerini şekillendiren bir kavram olduğu ifade edilmektedir. Modada meydana gelen değişiklikler bireyleri kullandığı ürünleri değiştirmesi için motive edebilmektedir. Moda bireylerin zaman içinde sahip olduğu alışkanlıkları değiştirebilmekte, bunun yanında bireyleri piyasaya sunulan yeni ürünleri satın almaya teşvik ettiği savunulmaktadır (Davis, 1997: 16). Modanın bireylerde farklılaşma ayrıcalığı olarak algılanmasında kuşkusuz medyanın önemli derecede rolü vardır. İşletme tarafından imal edilen ürünlerin pazarlanma sürecinde medyanın önemli rolü olduğu düşünüldüğünde hedef kitleye sunulan ürünlerin moda olabilmesi pazarlama faaliyetleri açısından önem arz etmektedir. Moda, medya araçlarının katkısı ile bireylerde değişim arzusu yaratıp, birçok ürüne yönelik ihtiyacı tetikleyen olgudur (Simmel, 2003: 103). Medya araçlarından bireylerin değişim arzusunu tetikleyen en önemli araç ise reklamlardır. Reklamlar hedef kitle olan bireylere tanıtım yaptığ ürünler hakkında bilgi verirken bunun yanında ürünlere artı değerler de yükleyerek bireylerin tutumlarını şekillendirebilmektedir. Reklamlar tarafından ürünlere artı değerler yüklenmesi sonucunda bireyler tutumlarını farklı olma ve ayırt edilebilme duyguları ile oluşturmaktadır. Crane (2003: 23) moda olan ürünlerin bireylerin tutumlarında ön planda olduğunu saptamıştır. Bu açıdan günümüzde birey tutumlarının şekillenmesinde ürün seçimi aşamasında moda önemli bir özelliktir. Çünkü moda olamayan bir ürün veya hizmet tüketiciler tarafından tercih edilmeyeceğinden işletmenin karlılığı artırıp devamlılığını sağlaması için moda unsurunu dikkate almalıdır. Bu nedenle işletmeler tarafından imal edilecek ürün veya hizmetlerin hedef kitleye başarılı reklam faaliyetleri ile sunularak moda olabilmesi pazarlama stratejileri açısından son derece önem arz ettiği ifade edilebilir.

\section{Logo}

"Belirli bir marka için tasarlanmış olan, özel bir tipografiyle ve belirli bir biçimde yazılan, tüm ortamlarda aynı biçimde yazılan marka adına "logo" denilmektedir. Logolar genellikle bir "amblem"le birlikte yer almakta ve "logo" sözcüğü de bu nedenle genellikle yazı ve görsel işaret bileşimini tanımlamak amacıyla kullanılmaktadır" (Gülsoy, 1999: 26). Ürünü temsil eden logo ve amblemin tüketici tarafından markaya olumlu imaj sergilemesinde etkili bir özellik olduğu ifade edilmektedir. Bunun yanında markalı ürünü temsil eden logo ve amblem hedef kitle olan bireylerin zihninde kalıcılığı sağlarken, ürünlerin hatırlanabilirliliğine de katkıda bulunmaktadır. Logo; ürünün, işletmenin ya da hizmetin isminin, harf ve görsel öğeler kullanılarak sembolleştirilmesi işlevidir. İşletmeler Logo oluştururken bazı kurallara dikkat etmektedir. Logo kolay anlaşılır, hatırlanması kolay ve az sayıda renkten oluşmalıdır. Ayrıca logonun birçok baskı ve kesim tekniği ile kullanımı kolay olmalı ve dağınık tasarlanmamalıdır. Tasarlanacak logo hedef kitle olan bireyler tarafından her türlü ölçüde ve yüzeyde kolay 
okunabilmelidir. Aynı zamanda İşletmeler tarafından seçilecek logolar rakip işletmelerin ürünlerine ait logolar ile karışıklığa imkan vermemelidir (Knapp, 2002: 88).

\section{Yöntem}

\subsection{Araştırmanın Amacı}

$\mathrm{Bu}$ araştırmada amaç ürün özelliklerine yönelik tutumların belirlenmesi amaçlanmaktadır. Bu nedenle araştırmanın temel amacı, ürün özelliklerine ait ifadelerin hangilerinin ön planda olduğuna yönelik tutumlarının belirlenmesi ve aşağıdaki alternatif hipotezlerin test edilmesidir.

- H1: Hedef kitlenin tutumlar üzerinde ürün özelliklerinin rolü vardır

- H2: ürün özelliklerinden logo ve amblem tutumlar üzerinde rolü vardır

- H3: ürün özelliklerinden modanin tutumlar üzerinde rolü vardır

\subsection{Araştırmanın Kapsamı}

Hedef kitlenin ürün özelliklerine yönelik tutumlarını tespit etmek ve hangi unsurların ön planda olduğunu belirlemek amacıyla, KKTC'nin 3 ilçesinde bir alan araştırması yürütülmüştür.

\subsubsection{Araştırma Bölgesinin Seçimi}

Alan araştırması KKTC'de 6 ilçeden örneklem alınarak da gerçekleştirilebilir. Ancak zaman ve ekonomik kaynaklar bakımından bir takım sınırlamalara gidilmesi nedeniyle araştırma Lefkoşa, Gazimağusa ve Girne ilçeleri ile sınırlandırılmıştır. Alan araştırmasının bu ilçelerde planlanma nedeni; söz konusu ilçelerde bu kapsamda akademik bir çalışmanın daha önce yapılmamış olması, nüfus yoğunlukları bakımından KKTC'nin en büyük üç ilçesi olması nedeniyle anket uygulanacak cevaplayıcıları belirlemede kolaylık sağlaması ve araştırmacının seçilen üç ilçeyi iyi tanıması olarak sıralanabilir. Araştırma örneklemi Lefkoşa, Gazimağusa ve Girne ilçelerinde sosyo-ekonomik olarak farklılık gösteren çeşitli bölgelerinde gerçekleştirilmiştir.

\subsubsection{Araştırma Bölgesine İlişkin Genel Bilgiler}

1983 yılında Kıbrıs Adasının kuzeyinde kurulan Kuzey Kıbrıs Türk Cumhuriyeti'nde Lefkoşa, Gazimağusa, Girne, Güzelyurt, İskele ve Lefke olmak üzere toplam 6 ilçe bulunmaktadır. 2011 verilerine göre toplam nüfusu 286.257 olan KKTC'nin nüfus yoğunluğu bakımından en kalabalık ilçeleri sırası ile Lefkoşa, Gazimağusa ve Girne'dir. Bu ilçelerdeki toplam nüfus 233.728 iken, 135.678 kişi nüfusun 18 yaş ve üzerini oluşturmaktadır. Nüfus dağılımları tablo 3 'te sunulmuştur.

\subsubsection{Cevaplayıcıların Seçimi}

Araştırmanın yapılacağı Lefkoşa, Gazimağusa ve Girne ilçelerinde 18 yaş ve üzeri tüketiciler olasılıklı olmayan örnekleme yöntemi ile belirlenmiştir.

Araştırmada görüşülecek kişilerin cinsiyet bazında dağılımı 2011 Devlet Planlama Örgütü yüzdelikleri dikkate alınarak kadın ve erkek cevaplayıcıların sayılarının birbirine yakın olmasına dikkat edilmiştir. Çalışmada zaman ve ekonomik 
imkanlar bakımından sınırlılıklar olması araştırmada görüşülecek cevaplayıcıların sayısında sınırlama yapılmasını gerekli kılmaktadır. Bu nedenle örneklem büyülüğü ve standart örneklem hatası 0.05 baz alınarak araştırmaya dahil edilecek cevaplayıcılar 480 kişi olarak sınırlandırılmıştır. Örneklem büyüklüğü dağılımları tablo $4^{\prime}$ te sunulmuştur. Buna göre araştırmada Lefkoşa, Gazimağusa ve Girne ilçelerinde ikamet eden bireyler arasından olasılıklı olmayan örnekleme yoluyla 480 kişi ile yüz yüze görüşülerek anket uygulanmıştır.

\subsection{Veri Toplama Yöntemi ve Araçları}

Araştırma kapsamına dahil edilen kadın ve erkek cevaplayıcıların ürün özelliklerine yönelik görüşlerinin saptanmasına yardımcı olacak verilerin elde edilmesinde anket tekniğinden yararlanılmıştır.

\subsubsection{Anket Formunun Hazirlanması}

Anket formu konu ile ilgili Türkçe ve yabancı kaynaklarda yer alan kavramsal ve kuramsal tanımlar ile araştırmalardan yararlanılarak hazırlanmıştır. Anket formu iki bölümden oluşmaktadır. İlk bölümde araştırma kapsamındaki hedef kitleye ilişkin demografik bilgileri içeren sorular yer almaktadır. Bu kapsamda tüketicilerin meslek, cinsiyet, yaş, öğrenim durumu, medeni durum, gelir durumu, ve yaşamakta oldukları ilçeye ilişkin sorular yer almaktadır.

Anketin ikinci bölümde ise hedef kitlenin ürün özelliklerine yönelik görüşlerini belirlemek amacıyla 6 cümle yer almaktadır. Araştırmaya katılan katılımcıların bu cümlelere katılım ve durumlarını tespit edecek cümleler şöyledir:

“Ürünün üretildiği ülke satın alma davranışımda etkilidir", "ürünün yerli ürün olup-olmaması satın alma davranışımda etkilidir", "ürünün moda olması satın alma davranışımda etkilidir", "ürünün marka bilinirliği satın alma davranışımda etkilidir", "ürünün ambalajı satın alma davranışımda etkilidir", "ürünün logosu, amblemi satın alma davranışımda etkilidir".

Ayrıca katılımcıların ürün özelliklerine yönelik görüşlerini ölçmek amacıyla oluşturulan ifadelerin güvenirliği 0,81 olduğu tespit edilmiştir. Kayış (2009: 405) tarafından güvenirlik (Cronbach's Alpha) katsayısının bulunabileceği aralıklar ve ölçeğin güvenirlik durumu; “ $0,6 \leq \alpha<0,80$ ” ise ölçek oldukça güvenilir, “ $0,80 \leq \alpha<1,00$ ” ise ölçek yüksek derecede güvenilir olarak kabul edilmektedir.

\subsubsection{Anket Formunun Uygulanmasi}

Araştırmada 480 kişiyle yüz yüze görüşme yoluyla anket uygulanmıştır. Anket, Lefkoşa, Gazimağusa ve Girne ilçelerinde araştırmacının kendisi tarafından gerçekleştirilmiştir. Anket formunun uygulanması sırasında cevaplayıcıları etki altında bırakabilecek ifade ve davranışlardan kaçınılmıştır. Ayrıca cevaplayıcıların samimi cevaplar verebilmesi amaciyla kimlik ve adres bilgileri ile ilgili sorular yöneltilmemiştir. 


\section{Verilerin Değerlendirilmesi}

Çalışma sonucunda elde edilen veriler bilgisayar ortamında bir istatistik yazılım programı aracılığıyla analiz edilmiştir. Analizlerde öncelikle tüketicilerin ürün özelliklerine yönelik görüşleri ölçeğinde yer alan ifadelere yapı geçerliğine ilişkin varimax rotasyonu ve temel bileşenler (principal components) yöntemi kullanılarak faktör analizi uygulanmıştır. Faktör analizinin uygulanabilirliği Bartlett testi, örneklem hacminin yeterliği ise Kaiser-Meyer-Olkin (KMO) değeri ile kontrol edilmiştir ve ölçeklerin iç tutarlığına yönelik güvenirlik analizi için Cronbach's Alpha değerleri hesaplanmıştır.

Araştırmada tüketicilerin ürün özelliklerine yönelik görüşlerinin belirlenmesi amacıyla yer alan ifadeler; kesinlikle katılıyorum (5), katılıyorum (4), kararsızım (3), katılmıyorum (2), kesinlikle katılmıyorum (1) şeklinde değerlendirilmiştir.

Araştırmada verilerin normal dağılımına ve homojenliğine ilişkin uygun testler yapılmış olup, p değerlerinin 0,05'ten büyük olması ve küçük olması durumuna göre parametrik veya parametrik olmayan testler tercih edilmiştir. Dolayısıyla tüketicilerin eğitim durumlarına ilişkin farklılık analizleri hariç diğer demografik bilgilerin farklılık analizinde parametrik testler uygulanmıştır. Hedef kitlenin görüşlerinin bireysel özelliklere göre karşılaştırılmasında bağımsız örneklemler için $t$ testi (independent samples $t$ test) ve (ikiden fazla grup için) tek yönlü varyans analizi (one way ANOVA) kullanılmış olup; varyans analizi sonucunda farklılık bulunan grupların ikili olarak karşılaştırılmasında ise Tukey testinden yararlanılmıştır. Tüketicilerin eğitim durumları ile ilgili alt boyutların karşılaştırılmasında ise parametrik olmayan testlerden bağımsız iki grubun karşılaştırılmasında Mann-Whitney $U$ Testi ve birbirinden bağımsız ikiden fazla grubun karşılaştırılmasında Kruskal-Wallis H Testi uygulanmıştır. Araştırmada tüketicilerin cinsiyet ve medeni durum özellikleri dikkate alınıp, ortalamalar arasındaki farkın önem kontrolü için bağımsız t-testinden faydalanılmıştır. Yaş, gelir durumu ve ilçe değişkenlerine göre ürün özelliklerine yönelik görüşlerin karşılaştırılmasında Tek Yönlü Anova testi'ne ihtiyaç duyulmuştur.

\subsection{Katılımcıların Ürün Özelliklerine İlişkin Görüşleri}

Çalışmada, bireylerin ürün özelliklerine yönelik görüşlerini belirlemek amacıyla hazırlanan toplam 5 ifade; kesinlikle katılıyorum (5), katıliyorum (4), kararsızım (3), katılmıyorum (2), kesinlikle katılmıyorum (1) biçiminde değerlendirmeye alınmıştır.

Katılımcıların "ürünün üretildiği ülke satın alma davranışımda etkilidir" ifadesine verdikleri cevaplar incelendiğinde \%47,9'unun bu ifadeye katılmadığı, \%34,8'inin kesinlikle katılmadığı, \%9,8'inin katıldığı, \%7,1'inin kesinlikle katıldığı ve $\% 0,4^{\prime}$ ünün ise kararsız olduğu saptanmıştır.

"Ürünün moda olması satın alma davranışımda etkilidir" cümlesine tüketicilerin katılma durumları değerlendirildiğinde; \%72,5'inin bu cümleye kesinlikle katıldığı, \%22,5'inin kesinlikle katıldığı, \%2,7'sinin kesinlikle katılmadığ katılmadığı ve \%0,6'sının kararsız olduğu tespit edilmiştir. 
“Ürünün marka bilinirliği satın alma davranışımda etkilidir"ifadesine tüketicilerin \%65,4'ünün kesinlikle katıldığı, \%34,4'ünün katıldığı ve \%0,2'sinin katılmadığı belirlenmiştir. Çalışmaya katılan bireyler arasında "kararsızım" ve “kesinlikle katılmıyorum” seçeneklerine görüş bildiren olmadığı saptanmıştır.

Araştırmaya katılan kişilerin "ürünün ambalajı satın alma davranışımda etkilidir" ifadesine yönelik vermiş olduğu yantlar değerlendirildiğinde; \%55'inin kesinlikle katıldığı, \%33,1'inin katıldığı, \%10,8'inin katılmadığı, \%0,6'sının kararsız olduğu ve \%0,4'ünün kesinlikle katılmadığı ortaya çıkmıştır.

Katılımcıların "ürünün logosu, amblemi satın alma davranışımda etkilidir" ifadesine katılma durumları incelendiğinde; \%74,2'sinin kesinlikle katıldığı, $\% 25,6$ 'sının katıldığ 1 ve \%0,2'sinin kararsız olduğu sonucu elde edilmiştir. Çalışmaya katılan tüketiciler arasında bu ifadeye 'katılmıyorum" ve "kesinlikle katılmıyorum" şeklinde görüş bildiren olmamıştır.

Tablo 1. Katılımcıların Ürün özelliklerine Yönelik Görüşlerindeki Alt Boyut İle Cinsiyet ve Medeni Durum Değişkenleri Arasındaki Farklılığın İncelenmesi (independent samples $t$ test)

\begin{tabular}{lllllll}
\hline Boyut/Faktör & Değişkenler & Gruplar & Ort. $\bar{X}$ & s.s. & T & P \\
\hline \multirow{4}{*}{ Cinsiyet } & Kadın & 4,17 & 0,47 & \\
\cline { 3 - 6 } Ürün Özellikleri & & Erkek & 4,18 & 0,42 & \\
\cline { 3 - 6 } & \multirow{2}{*}{ Medeni Durum } & Evli & 4,20 & 0,43 & \multirow{2}{*}{1,482} & 0,139 \\
\cline { 3 - 6 } & & Bekâr & 4,13 & 0,49 & \\
\hline
\end{tabular}

$$
{ }^{*} \mathrm{p}<0,05
$$

Araştırma kapsamındaki bireylerin ürün özelliklerine yönelik görüşlerindeki boyut ile cinsiyet ve medeni durum değişkenleri arasındaki farklılığın incelenmesi tablo 1'de t-testi (independent samples $t$ test) ile analiz edilmeye çalışılmıştır. Tüketicilerin ürüne yönelik görüşleri kapsamında belirlenen "Ürün Özellikleri" boyutuna ilişkin olarak cinsiyetlere göre $(p=-0,889 ; p>0,05)$ anlamlı bir farklılık tespit edilmemiştir.

Elde edilen bulgular sonucunda ürün özelliklerine yönelik görüş bildiren kadınlar $(\bar{X}=4,17)$ ve erkeklerin $(\bar{X}=4,18)$ benzer düşüncelere sahip olduğu anlaşılmaktadır. Öte yandan elde edilen veriler medeni durum değişkenine göre değerlendirildiğinde araştırmaya katılan evli bireylerin $(\bar{X}=4,20)$ bekârlara $(\bar{X}=4,13)$ ürünlerin moda olması, marka bilinirliği, ambalajı, logosu ve amblemi gibi unsurların daha fazla rolü olduğu tespit edilmiştir. 
Tablo 2. Katılımcıların Ürün Özelliklerine Yönelik Görüşlerindeki Alt Boyutu İle Yaş Değişkeni Arasındaki Farklılı̆̆ın İncelenmesi (Anova ve Tukey Testi)

\begin{tabular}{|c|c|c|c|c|c|c|c|}
\hline Değişken & Boyut/Faktör & Gruplar & Ort. $\bar{X}$ & s.s. & $\mathbf{F}$ & $\mathbf{P}$ & Tukey \\
\hline \multirow{4}{*}{ Yaş } & \multirow{4}{*}{ Ürün Özellikleri } & $18-27$ & 4,09 & 0,51 & \multirow{4}{*}{2,891} & \multirow{4}{*}{0,035} & \multirow{4}{*}{$\begin{array}{l}1-2 \\
2-1\end{array}$} \\
\hline & & $28-37$ & 4,25 & 0,43 & & & \\
\hline & & $38-47$ & 4,17 & 0,43 & & & \\
\hline & & $48 \geq$ & 4,14 & 0,42 & & & \\
\hline
\end{tabular}

Tablo 2' de sunulan katılımcıların ürün özelliklerine yönelik görüşlerindeki alt boyut ile yaş değişkeni arasındaki farklılığın incelenmesi tek yönlü varyans analizi ve farklılığın kaynağına yönelik Tukey testi ile test edilmiştir.

Ürün özellikleri alt boyutuna yönelik çalışmaya dahil edilen katılımcı görüşleri incelendiğinde; 18-27 yaş grubunda yer alan kişiler ile 28-37 yaş grubundaki bireyler arasında anlamlı farklılık $(\mathrm{p}=0,035 ; \mathrm{p}<0,05)$ olduğu anlaşılmaktadır. Elde edilen veriler kapsamında 18-27 yaş $(\bar{X}=4,09)$ grubundaki katılımcıların tutumlarında 28-37 yaş $(\bar{X}$ $=4,25$ ) arası tüketici grubuna göre ürün özelliklerinin daha az rolünün olduğu tespit edilmiştir. Bu bağlamda 18-27 yaş grubundaki tüketicilerin 28-37 yaş arası tüketici grubuna göre ürünlerin moda olması, marka bilinirliği, ambalajı, logo ve amblemi gibi unsurları daha fazla önemsediği belirlenmiştir.

Tablo 3. Katılımcıların Eğitim Durumu ile Ürün Özelliklerine Yönelik İfadelere İlişkin Alt Boyutunun Karşılaştırılması (Kruskal-Wallis H Testi)

\begin{tabular}{|c|c|}
\hline Eğitim Durumu & Ürün Özellikleri \\
\hline Okur-yazar değil $(\mathrm{n} / \bar{X})$ & $3 / 340,00$ \\
\hline Okur-yazar $(\mathrm{n} / \overline{\mathrm{X}})$ & $10 / 343,10$ \\
\hline İlkokul (n/ $\bar{X})$ & $19 / 243,87$ \\
\hline Ortaokul $(n / \bar{X})$ & $48 / 256,81$ \\
\hline Lise $(n / \bar{X})$ & $201 / 238,69$ \\
\hline Üniversite $(n / \bar{X})$ & $188 / 231,02$ \\
\hline Yüksek Lisans/ Doktora $(\mathrm{n} / \overline{\mathrm{X}})$ & $11 / 238,09$ \\
\hline Chi-Square & 8,759 \\
\hline $\mathbf{P}$ & 0,188 \\
\hline Mann Whitney U Testi & - \\
\hline
\end{tabular}




\subsection{Tüketicilerin Eğitim Durumu Değişkenine Göre Ürün Özelliklerine Yönelik Görüşleri}

Tablo 3'te katılımcıların eğitim durumu ile ürün özelliklerine yönelik ifadelere ilişkin alt boyutunun karşılaştırılması için yapılan Kruskal-Wallis H Testi ve farklılığın kaynağını belirlemek amacıyla yapılan Mann Whitney U Testi sonuçları sunulmuştur. $\mathrm{Bu}$ test sonuçlarında tüketicilerin ürüne yönelik görüşleri karşılaştırılmış; "Ürün Özellikleri" ve "Satış Özellikleri" boyutlarında katılımcıların eğitim durumlarına göre farklılığın olmadı̆̆ belirlenmiştir ( $p=0,188 ; p>0,05 ; p=0,866>0,05)$. Ancak bu boyut içinde ortalamalar dikkate alındığında yüksek ve düşük değerler söz konudur. Bu bağlamda bireylerin "ürün özellikleri" alt boyutuna yönelik görüşleri eğitim durumlarına göre değerlendirildiğinde; eğitim seviyesi okur-yazar $(\bar{X}=343,10)$ olan bireylerin satın alma davranışlarında ürün özelliklerinin rolünün eğitim seviyesi yüksek lisans/doktora $(\bar{X}=238,09)$ olan tüketicilere göre daha fazla olduğu tespit edilmiştir. Bu bağlamda eğitim seviyesine bağlı olarak bilinçlenen kişilerin ürünlerin moda olması, marka bilinirliği, ambalajı, logosu ve amblemi gibi özellikleri aldırış etmeden satın alma tutumu sergilediği söylenebilir.

Tablo 4. Katılımcıların Ürün Özelliklerine Yönelik Görüşlerindeki Alt Boyutu İle İlçe

Değişkeni Arasındaki Farklılığın İncelenmesi (Anova ve Tukey Testi)

\begin{tabular}{|c|c|c|c|c|c|c|c|}
\hline Değişken & Boyut/Faktör & Gruplar & Ort. $\bar{X}$ & s.s. & $F$ & $\mathbf{P}$ & Tukey \\
\hline \multirow{5}{*}{ İlçe } & \multirow{5}{*}{ Ürün Özellikleri } & Lefkoşa & 4,25 & 0,37 & \multirow{5}{*}{6,217} & \multirow{5}{*}{$0,002^{*}$} & \multirow{5}{*}{$\begin{array}{c}1-2,3 \\
2-1 \\
3-1\end{array}$} \\
\hline & & Gazimağusa & 4,14 & 0,46 & & & \\
\hline & & Girne & 4,09 & 0,54 & & & \\
\hline & & Gazimağusa & 4,15 & 0,31 & & & \\
\hline & & Girne & 4,14 & 0,32 & & & \\
\hline
\end{tabular}

${ }^{*} \mathrm{p}<0,05$

\subsection{Katılımcıların İlçe Değişkenine Göre Ürün Özelliklerine Yönelik Görüşleri}

Katılımcıların ürün özelliklerine yönelik görüşlerine ilişkin alt boyutu ile ilçe değişkeni arasındaki farklılığın incelenmesi tek yönlü varyans analizi ve farklılığın kaynağına yönelik Tukey testi sonuçları tablo $4^{\prime}$ te sunulmuştur. Belirlenen sonuçlara göre hem "Ürün Özellikleri" ( $p=0,002 ; p<0,05)$ alt boyutuna ilişkin elde edilen değerler analiz edildiğinde Lefkoşa ilçesinde yaşayanlar ile Gazimağusa ve Girne ilçelerinde yaşayanlar arasında anlamlı farklılıklar tespit edilmiştir.

"Ürün Özellikleri" boyutuna yönelik katılımcı görüşleri ilçelere göre incelendiğinde elde edilen bulgulara göre ürün özelliklerinin Lefkoşa $(\bar{X}=4,25)$ ilçesinde yaşayan tüketicilerin tutumlarında en fazla rolü olduğu belirlenirken, Girne ( $\bar{X}=4,09$ ) ilçesinde ikamet eden hedef kitle grubunun tutumlarında ürün özelliklerinin en az rolü olduğu saptanmıştır. Görüşü alınan katılımcı sonuçlarına göre Lefkoşa'da ( $\bar{X}=4,25)$ ikamet edenlerin, Gazimağusa $(\bar{X}=4,14)$ ve Girne $(\bar{X}=4,09)$ ilçelerinde ikamet eden kişilere göre ürünlerin moda olması, marka bilinirliği, ambalajı, logosu ve amblemi gibi özelliklerin daha ön planda olduğu saptanmıştır. 
Tablo 5. Katılımcıların Ürün Özelliklerine Yönelik Görüşlerindeki Alt Boyutu İle Aylık Gelir Değişkeni Arasındaki Farklılığın İncelenmesi (Anova ve Tukey Testi)

\begin{tabular}{|c|c|c|c|c|c|c|c|}
\hline Değişken & Boyut/Faktör & Gruplar & Ort. $\bar{X}$ & s.s. & $\mathbf{F}$ & $\mathrm{p}$ & Tukey \\
\hline \multirow{6}{*}{ Aylık Gelir } & \multirow{6}{*}{$\begin{array}{c}\text { Ürün } \\
\text { Özellikleri }\end{array}$} & $750 \mathrm{TL} \leq$ & 4,06 & 0,47 & \multirow{6}{*}{2,949} & \multirow{6}{*}{0,020} & \multirow{6}{*}{$\begin{array}{l}4-5 \\
5-4\end{array}$} \\
\hline & & 751-1500TL & 4,28 & 0,45 & & & \\
\hline & & 1501-2250TL & 4,19 & 0,45 & & & \\
\hline & & $2251-3000 \mathrm{TL}$ & 4,21 & 0,44 & & & \\
\hline & & $3001 \mathrm{TL} \geq$ & 4,02 & 0,43 & & & \\
\hline & & $3001 \mathrm{TL} \geq$ & 4,08 & 0,33 & & & \\
\hline
\end{tabular}

${ }^{*} \mathrm{p}<0,05$

\subsection{Katılımcıların Gelir Durumu Değişkenine Göre Ürün Özelliklerine Yönelik Görüşleri}

Tüketicilerin ürün özelliklerine yönelik görüşlerindeki alt boyut ile aylık gelir değişkeni arasındaki farklılıklar incelendiğinde; katılımcıların ürün özellikleri $(p=0,020 ; p<0,05)$ alt boyutu ile gelir grupları arasında anlamlı farklılıklar olduğu tespit edilmiştir (Tablo 5). Ürün özellikleri alt boyutu ile gelir grupları arasındaki farklılık 2251-3000TL arası gelire $(\bar{X}=4,21)$ sahip olan katılımcılarla 3001TL ve üzeri gelire $(\bar{X}$ $=4,02)$ sahip olan katılımcilar arasında saptanmıştır. Aritmetik ortalamalar dikkate alındığında; aylık geliri 3001TL ve üzeri olan kişilerin, kazancı 2251-3000TL arasında olan kişilere göre ürünlerin moda olması, marka bilinirliği, ambalajı, logosu ve amblemi gibi özelliklerin daha az rolü olduğu belirlenmiştir.

Tablo 6. Katılımcıların Ürün Özelliklerine Yönelik Görüşlerindeki Alt Boyutu İle Meslek Değişkeni Arasındaki Farklılığın İncelenmesi (Anova ve Tukey Testi)

\begin{tabular}{|c|c|c|c|c|c|c|c|}
\hline Değişken & Boyut/Faktör & Gruplar & Ort. $\overline{\mathrm{X}}$ & s.s. & $\mathbf{F}$ & $\mathbf{P}$ & Tukey \\
\hline \multirow{7}{*}{ Meslek } & \multirow{7}{*}{$\begin{array}{c}\text { Ürün } \\
\text { Özellikleri }\end{array}$} & Öğrenci & 4,23 & 0,42 & \multirow{7}{*}{1,548} & \multirow{7}{*}{0,161} & \multirow{7}{*}{-} \\
\hline & & Ev Hanımı & 4,28 & 0,44 & & & \\
\hline & & Memur & 4,12 & 0,48 & & & \\
\hline & & İşçi & 4,22 & 0,39 & & & \\
\hline & & Serbest Meslek & 4,22 & 0,45 & & & \\
\hline & & Esnaf & 4,04 & 0,43 & & & \\
\hline & & Diğer & 4,10 & 0,47 & & & \\
\hline
\end{tabular}

${ }^{*} \mathrm{p}<0,05$

\subsection{Tüketicilerin Meslek Değişkenine Göre Ürün Özelliklerine Yönelik Görüşleri}

Tablo 6'da katılımcıların meslek değişkeni kapsamında ürün özelliklerine yönelik görüşlerine ilişkin Tek Yönlü Varyans Analizi ve Tukey testi sonuçları sunulmuştur. Katılımcıların “Ürün Özellikleri” boyutunda yer alan ifadelere yönelik verdikleri cevaplar meslek grupları açısından anlamlı farklılık göstermemektedir $(\mathrm{p}=0,161 ; \mathrm{p}>0,05)$. 


\section{SONUÇ VE TARTIŞMA}

İletişim alanındaki değişimlere paralel olarak günümüzde teknolojik gelişmelerinde katkısıyla artan ürün çeşitliliği sonucunda bireyler birçok ürün arasından seçim yapma noktasında kararsız kalabilmektedir. Bireyler, ürünler arasından tercih yaparken sahip olduğu tutum doğrultusunda karar verebilmektedir. Oluşan tutumlar ise ürünlerin özellikleri dikkate alınarak şekillenmektedir. $\mathrm{Bu}$ bakımdan gelinen noktada ürün özelliklerinin bireylerin tutumları üzerindeki etkisi önemli hale gelmiştir. Bu çalışmada ise görüşü alınan katılımcıların ürün özelliklerine yönelik görüşleri belirlenmeye çalışılmıştır. Çıkan sonuçlar değerlendirildiğinde; ürün özelliklerinin en fazla evli bireylerin tutumlarında rolü olduğu saptanmıştır. Öte yandan ürün özelliklerinin en fazla "28-37 yaş” grubundaki bireylerin satın alma tutumunda etkili olduğu belirlenmiştir. Bu bağlamda; ürünün logosu, amblemi, ambalajı, marka bilinirliği ve moda olması gibi unsurların görüşü alınan 28-37 yaş arasındaki bireylerin diğer yaş gruplarına oranla satın alma tutumlarında daha ön planda olduğu söylenebilir. Bireylerin eğitim durumları itibariyle ürün özelliklerine yönelik görüşleri ise ürün özelliklerinin en fazla okur-yazar olan tüketici tutumlarında etkili olduğu ortaya çıkmıştır. Dolayısıyla çalışmaya dahil edilen katılımcıların eğitim seviyesi düştükçe tutumların belirlenmesinde ürün özelliklerinin rolünün daha fazla olduğu anlaşılmaktadır. Anket kapsamına alınan bireylerin ürün özellikleri açısından görüşleri ilçelere göre değerlendirildiğinde; Lefkoşa ilçesinde ikamet eden bireyler Gazimağusa ve Girne ilçelerinde ikamet eden bireylere oranla tutumlarında ürün özelliklerinin rolünün daha fazla olduğu tespit edilmiştir. Medeni durum değişkenine göre katılımcı görüşleri analiz edildiğinde; evli bireylerin bekârlara oranla tutumlarında ürün özelliklerinin daha fazla rolü olduğu belirlenmiştir. Aylık gelirlerine göre kişilerin ürün özelliklerine ilişkin görüşleri arasındaki farklılıklar değerlendirildiğinde; 751-1501 TL arasında gelire sahip bireylerin, geliri 3000TL ve üzerinde olan bireylere oranla tutumlarının belirlenmesi noktasında ürünün moda olması, marka bilinirliği, ambalajı, logo ve amblemi gibi özelliklerin daha fazla rolü olduğu anlaşılmıştır. Bu doğrultuda bireylerin gelir seviyesi yükseldikçe daha lüks sinıf ürünleri benimsedikleri ifade edilebilir.

\section{KAYNAKÇA}

Altunışık, R. ve Baş, Y. (2015). Tüketicilerin Ürün Satınalma Kararları Öncesi Aradıkları Bilgi Türlerinin Sınıflandırılması Üzerine Bir Araştırma, Bilgi Ekonomisi ve Yönetimi Dergisi, 10(1),

Baban, E. (2010). İkon Markaların Tüketici Satın Alma Davranışı Üzerine Etkisi: Lüks Markalara Yönelik Araştırma, (Yayınlanmamış Doktora Tezi). İstanbul: Marmara Üniversitesi Sosyal Bilimler Enstitüsü.

Berkman, W., Jay, D. ve Joseph S. M. (1997), Consumer Behavior, NTC Business book, Lincolnwood Chicago.

Batur, E. (1987). Gelenek ve Gelecek Arasinda Moda, İstanbul: Gergedan Yayınları, Sayı:92.

Baybars, T.Ö. (1999). Pazarlama ilkeleri. Global Yönetimsel Yaklaşım Türkiye Uygulamaları 8. 
Bozkurt, İ. (2000). Küreselleşme: Kavram, Gelişim ve Yaklaşımlar, V. Bozkurt (Derl.), Küreselleşmenin İnsani Yüzü, Bursa: Alfa Yayınları.

Brody, A.L. ve Lord, J.B. (2000). Developing New Food Products for a Changing Marketplace. Boca Raton, Florida: CRC Pres.

Copeland, M.T. (1924). Principles of Merchandising, Chicago: A. W. Shaw Co.

Crane, D. (2003). Moda ve Gündemleri Giyimde Sınıf, Cinsiyet ve Kimlik, (Çeviren: Özge Çelik), İstanbul: Ayrıntı Yayınları.

Çalışkan, G. (2008). firma satış destek elemanının (merch) tüketicinin satınalma davranışına etkisi üzerine bir araştırma (Yayınlanmamış yüksek lisans tezi). Adapazarı: Sakarya Üniversitesi Sosyal Bilimler Enstitüsü.

Çevikbaş, E. (2007). Marka Bilinirliğinin Tüketici Satın Alma Davranışı Üzerine Etkileri ve Elektrikli Küçük Ev Aletleri Üzerine Bir Uygulama (Yüksek Lisans Tezi). Sakarya: Sakarya Üniversitesi İşletme Ana Bilim Dalı.

Davis, F. (1997). Moda, Kültür ve Kimlik, (Çeviren: Özden Arıkan), İstanbul: Yapı Kredi Yayınları.

Devlet Planlama Örgütü. (2011). İlçelere Ait Veriler http://www.devplan.org/frame tr.html (Erişim tarihi: 24 Şubat 2016).

Gülsoy, T. (1999). Reklam Terimleri ve Kavramları Sözlüğ̈̈, İstanbul: Adam Yayınları.

İslamoğlu, A.H. ve Altunışık, R. (2008). Tüketici Davranışları (İkinci Baskı), İstanbul: Beta Basım Yayınları.

Knapp, D.E. (2002). Marka Aklı, (Çev. Akartuna, T.), İstanbul: MediaCat Kitapları.

McCracken, G.D. (1990). Culture and Consumption: New Approaches to the Symbolic Character of Consumer Goods and Activities, Bloomington: Indiana University Press.

Oğuz, S. (1997). Ürün, etiket ve ambalajın kalite imajı üzerine etkileri (Yayınlanmamış Yükseklisans Tezi), İmir: Dokuz Eylül Üniversitesi.

Scott, J.E. ve Gregg, D.G. (2004). The Impact of Product Clasification For Online Auctions, Tenth Americas Conference on Information Systems, August, New York.

Silayoi, P. and Speece, M. (2004). Packaging and purchase decisions, an exploratory study on the impact of involvement level and time pressure. British Food Journal.

Simmel, G. (2003). Moda feslefesi (T. Bora, Çev.). Modern Kültürde Çatışma içinde, İstanbul: İletişim Yayınları.

Taşyürek, N. (2010). Reklam ve Reklamın Tüketicilerin Satın Alma Davranışları Üzerindeki Etkisi: Bir Alan Araştırması (Yayınlanmamış Yüksek Lisans Tezi), Ankara: Atılım Üniversitesi Sosyal Bilimler Enstitüsü.

Tek, Ö.B. (1999). Pazarlama İlkeleri, İstanbul: Beta Yayınları.

Üçüncü, M. (2000). Gıdaların Ambalajlanması, İzmir: Ege Üniversitesi Basımevi.

Wilson, E. (2003). Adorned in Dreams: Fashion and Modernity, New Jersey: Rutgers University Press.

Yazıcıoğlu, Y. ve Erdoğan, S. (2004). Spss Uygulamalı Bilimsel Araştırma Yöntemleri. Ankara: Detay Yayıncılık. 